\title{
Technical Efficiency of Manufacturing Firms in Cameroon: Sources and Determinants
}

\author{
Ernest Ngeh Tingum ${ }^{1} \&$ Moses A. Ofeh ${ }^{2}$ \\ ${ }^{1}$ Faculty of Economics and Management Sciences, University of Bamenda, Bambili, Cameroon \\ ${ }^{2}$ Department of Economics, Higher Teacher Training College, University of Bamenda, Cameroon \\ Correspondence: Ernest Ngeh Tingum, Faculty of Economics and Management Sciences, University of Bamenda. \\ P.O Box 39, Bambili, Cameroon.
}

Received: April 28, 2017

Accepted: May 17, 2017

Online Published: July 18, 2017

doi:10.5430/ijfr.v8n3p172

URL: https://doi.org/10.5430/ijfr.v8n3p172

\begin{abstract}
The primary objective of this study is to analyze the determinants of efficiency in manufacturing firms in Cameroon. The study used a stochastic frontier model employing RPED data of 319 firms from different manufacturing industries. The data are micro-level which is the most adequate type of data used in the estimation of these models. The model used is that outlined by Battese and Coelli (1995) which determines the causes of inefficiency in the manufacturing sector in Cameroon. The estimates of the stochastic production frontier with inefficiency effects model indicates that firms in Cameroon exhibit various degrees of technical inefficiency for the sample of firms considered. The results show that firm size plays an important role in explaining technical efficiency in the sub-sector of food processing. However, large firms reduce technical inefficiency levels of firms in all the sub sectors. Another important variable which has an effect in determining technical efficiency level is the foreign ownership variable. It is significant in food processing, wood processing, textile and garments as well as in the overall sample. Hence, it increases technical efficiency in all the sub-sectors. Finally, since an increase in age of firms leads to a reduction in efficiency levels in manufacturing firms, policies should be adopted to replace the existing capital in the large firms.
\end{abstract}

Keywords: Cameroon, manufacturing, maximum likelihood estimates, stochastic frontier technical efficiency

\section{Introduction and Background}

The manufacturing sector has played an important role in Cameroon since its independence with productivity enhancement being crucial to the drive for rapid industrialization and economic growth (Njikam and Cockburn, 2007). The sector employs around 9.2 percent of the total labor force, supplies its output both in domestic and foreign markets, generates foreign exchange receipts (up to 35 per cent of export receipts) and contributes up to 17.5 percent to the Gross Domestic Product (GDP) at current prices ${ }^{3}$. Moreover, manufacturing induces most of the linkage effects on the other sectors of the economy, thus contributing to export diversification, job creation, and poverty reduction (National Institute of Statistics (NIS), 2009).

However, the performance of the sector has been declining in recent years. According to NIS (2009), the drop may be attributed to the declining number of firms leading to a continuous fall in output. Evidence from literature points to the decline in manufactured commodity prices, appreciation of the 'Communauté Financière de l'Afrique (CFA) franc' relative to the US dollar, and certain domestic distortions such as high cost of inputs, a cumbersome administrative machinery, poor management of public enterprises, poor macroeconomic policy, and cutbacks in government subsidies to firms as the main causes of the fall in manufactured output (Njikam et al., 2008).

Therefore, low and inadequate manufacturing firms' output in Cameroon may potentially be explained by the fact that most of the firms are old (20 years and above) and still use the obsolete technology with little or no technological change. This may lead to both high technical and allocative inefficiencies. Although some of the factors that lead to low productivity in firms have been identified (Soderling, 1999; Njikam, 2003; 2007), economic and institutional factors that are expected to have significant effect on technical efficiency of manufacturing firms in Cameroon are still not well empirically established. The paper focuses on estimating technical efficiency and factors influencing technical inefficiencies of manufacturing firms in Cameroon. 
The rest of the paper is organized as follows. In section two, some empirical literature on productivity and efficiency studies in Cameroon are reviewed. Section three provides the methodology for the study. In section four, the estimated coefficients are reported and results are equally discussed. Section five gives conclusions and policy implications.

\section{Studies on Cameroon Manufacturing Firms}

Soderling (1999) used firm level data covering the period 1980 - 1995 to present main developments in the manufacturing industry in Cameroon. The study laid more emphasis on structural factors of competitiveness. A production function and an export function were estimated in order to study the determinants of total factor productivity (TFP) and export performance. The results provided evidence indicating that openness to trade, development of skilled labor and adequate management of the real exchange rate were crucial factors in the enhancement of productivity and exports. The simple model used to quantify these impacts revealed that the devaluation of the CFA franc in 1994 had some appreciably beneficial effects on manufacturing productivity and exports. More so, Soderling (1991) demonstrated a mutually reinforcing relationship between productivity and export performance and constructed a model to assess the cost of Real Effective Exchange Rate (REER) evaluation, both in terms of productivity and exports. The study showed that performance of the manufacturing sector in Cameroon deteriorated considerably after the mid-1980s. The decline was to a large extent explained by in-ward looking policies in the manufacturing sector.

Njikam (2003) using firm-level data to establish the trade reform efficiency on Cameroonian manufacturing firms reported a positive (but statistically insignificant) association between the official tariff rates and the level of average technical efficiency achieved by firms. The author also found the association between effective protection rate and the level of mean technical efficiency in the manufacturing firms to be positive but statistically insignificant. Further, the study observed a strong positive association between import penetration ratio and the level of mean technical efficiency achieved in the manufacturing industry. Even though the results obtained by Njikam conformed to the $a$ priori expectation of a positive relationship between the two variables. However, the results were obtained from a correlation analysis which does not provide a basis for measuring the impact of one variable on the other.

The results of Njikam (2000) indicated a positive and significant correlation between manufacturing share of exports and average technical efficiency achieved in the Cameroonian manufacturing sector. The results showed that the higher the share of manufacturing in total exports, the higher the mean technical efficiency achieved in the manufacturing sector. The study also reported a positive and significant association between changes in import penetration rate, export share, effective rate of protection and intra-industry trade index and the mean technical efficiency achieved in the firms. Further, a negative and insignificant correlation between changes in official tariff rates and the mean technical efficiency were found. Moreover, the results indicated that, while macroeconomic instability (inflation) had a negative and statistically significant impact on average technical efficiency achieved in the sector, the impact of political instability on the mean technical efficiency was also negative but statistically insignificant. The author also revealed that the impact of property right protection on mean technical efficiency is positive and statistically significant. The results imply that political and macroeconomic instability hindered efficiency of manufacturing sector while property rights protection promoted manufacturing sector's efficiency in Cameroon.

Njikam and Cockburn (2007) used pooled pre and post reform period data (from 1988/89 to 1991/92 and from 1994/95 to 1997/98) for Cameroon manufacturing firms to estimate a single stochastic production frontier for each industrial sector. Such a frontier was used to assess the effects of trade reforms in manufacturing firm-level technical efficiency. A Cobb-Douglas production function was specified and estimated for the production frontier. The link between trade reforms and firm-level technical efficiency was established using a two-stage procedure. In the first stage, the production frontier parameters were estimated and firm-level technical efficiencies derived. In the second stage, the derived firm-level technical efficiencies were regressed on trade policy and macroeconomic variables to assess the impact of trade reform and macroeconomic variables.

The results suggested that trade reforms provided an enabling environment for improving firm-level technical efficiency. Average technical efficiency increased in six of the eight sectors following trade reforms. The pre-reform firm-specific technical efficiencies decreased on average at an annual rate of 0.76 percent, while the post-reform firm-specific technical efficiency increased on average at an annual rate of 1.4 percent. Lastly, factors that characterize firm-level technical inefficiency prior to trade liberalization, as showed by the Tobit and fixed effects results were macroeconomic instability and political instability of the early 1990s, coupled with restricted trade regime. After the trade reforms, the potential determinants of firms' technical efficiency were export share and 
import penetration rate (Njikam et al., 2008).

Cameroon industrial policies raise different questions which the present study sheds light on. In explaining the gap, the following questions are asked: What are the determinants of Cameroon's manufacturing efficiency, and using such determinants, how efficient are the manufacturing firms in Cameroon across different industries?

\section{Methodology}

\subsection{The Sample of Cameroonian Manufacturing Firms and Variables}

The data set used in this section is obtained from the Regional Program Enterprise Development (RPED) dataset for Cameroon's manufacturing sector for the year 2009 captured by the World Bank's RPED survey of year 2010. The main objective of these surveys in African countries is to increase the knowledge of the creation process of African manufacturing firms and to shed some light on the problems they face in their development. The RPED defines formal firms as those recorded in the trade register. They are known to the government tax authorities and are potential taxpayers for all regular taxes resulting from their commercial activities.

The purpose of the survey in Cameroonian manufacturing was to capture business perceptions on the main obstacles to enterprise growth, the relative importance of various constraints to increasing employment and productivity, and the effects of the country's business environment on its international competitiveness. The sample consisted of 319 firms employing at least 5 permanent workers, and covering the following manufacturing sub-sectors: food processing, textile and garments, chemicals and pharmaceuticals, non-metallic, machinery and equipment, electronics and wood processing. The five sectors covered in the study represent approximately 76.18 per cent of total manufacturing in Cameroon (RPED, 2010). The food, wood and textile and garments sectors are the dominant sectors in terms of output and employment, followed by metals and machinery, electronics, chemical and pharmaceutical industries among others. During the years of import substitution, most resources were invested in the food sector, and later, during the 1980s, in the wood and other sectors. Because some of the investments in food and wood production were foreign, it has been suggested that these sectors are the most productive and technologically advanced. Output in the food sector comprises a wide range of commodities, including grain milling, dairy products, canning and preservation of meat, fruit and vegetables, bakery and confectionery, beverages, food preservatives and animal feed (Njikam and Cockburn, 2007).

An important advantage of the data set is that it enables one to test for inefficiency using truly microeconomic data. In fact, it has been found that empirical tests which rely on microeconomic data provide clearer evidence of inefficiency than studies that make use of more aggregate data, since there is a loss of information in the aggregation process (Schmidt and Lovell, 1979). Appendix 1 shows the distribution by size, the sector of activity and the ages of the firms. The greater proportion of medium size firms are 20 years old and above. Generally, there are more medium size firms in the sample, followed by large firms.

\subsection{Analytical Framework and Model Specification}

The specification of the stochastic frontier model is a production function with an error term incorporating two components: the output-based unobservable technical inefficiency factor $u_{i}$, and a symmetric component $v_{i}$, capturing random variations across production units and random shocks that are external to its control. Following Farrell (1957), Aigner and Chu (1968) the model is specified as;

$$
Y_{i}=f\left(X_{i}, \beta\right)+e_{i} ; \quad i=1,2, \ldots, N
$$

Where $Y_{i}$ represents the potential output level on the frontier for firm $i$, a given technology $f(),. X_{i}$ is a $(1 \times k)$

vector of inputs and other explanatory variables associated with the $i^{\text {th }}$ firm. $\beta$ is a $(k \times 1)$ vector of unknown parameters. The error term $e_{i}$ is composed of two independent elements, i.e., $e_{i}=v_{i}-u_{i}$, with the $v_{i}$ term being a random (stochastic) error, which is associated with random factors not under the control of the firm. It is assumed to be independently and identically distributed as $N\left(0, \sigma_{v}^{2}\right)$, where $\sigma_{v}^{2}$ stands for the variance of 
stochastic disturbance $v_{i}$. If industries achieve their maximum output, then they would be technically efficient and it means that $u_{i}=0 . u_{i}$ is associated with the technical inefficiency of the $i^{t h}$ firm and defined by the truncation (at zero) of the normal distribution $N\left(z_{i} \delta, \sigma_{u}^{2}\right)$, where $z_{i}$ is a $(1 \times m)$ vector of explanatory variables associated with technical inefficiency of firms; and $\delta$ is an $(m \times 1)$. Due to its ability to decompose the composite error term into a technical inefficiency term and a stochastic error term, the stochastic frontier analysis has been used in estimating technical efficiency.

The measure of efficiency is given as the ratio of the observed output of the $i^{\text {th }}$ firm to the potential output defined by the frontier function and is outlined as:

$$
T E_{i}=\frac{y_{i}}{\exp \left(x_{i} \beta\right)}=\frac{\exp \left(x_{i} \beta-u_{i}\right)}{\exp \left(x_{i} \beta\right)}=\exp \left(-u_{i}\right)
$$

It is assumed that the frontier has firm effects which are distributed as a truncated normal random variable, in which the inefficiency effects are directly influenced by a number of variables. Given the objectives of the study, the empirical model is specified as follows:

$$
\operatorname{In} Y_{i}=\beta_{0}+\beta_{1} \operatorname{In}\left(K_{i}\right)+\beta_{2} \operatorname{In}\left(L_{i}\right)+\beta_{3} \operatorname{In}\left(H_{i}\right)+\beta_{4} \operatorname{In}\left(R_{i}\right)+V_{i}+u_{i}
$$

where the four categories of inputs used in the study include: Capital (K), Labor (L), Human Capital (H) and intermediate inputs (R). In the study, depreciation allowances are used to measure the capital input (Lundvall et al., 2002). Labor input (L) is measured as total number of hours worked in the firm. Human capital captures the specific impact of human qualifications and intermediate inputs variable is measured as the expenditures on inputs (raw materials and supplementary materials such as solid and liquid fuel, electricity and water costs) adjusted for stock changes.

Knowing that firms are technically inefficient might not be useful unless the sources of the inefficiency are identified. Therefore, the second stage of the analysis investigates the firm specific attributes that influence its technical efficiency. The inefficiency function is specified as follows:

$$
\begin{aligned}
u_{i} & =\delta_{0}+\delta_{1} \text { firmsize }+\delta_{2} \text { age }+\delta_{3} \text { foreign }+\delta_{4} \text { union }+\delta_{5} \text { reglabor }+\delta_{6} \text { corruption }+\delta_{7} \text { taxrates } \\
& +\delta_{8} \text { accessfin }+\delta_{9} \text { Mngedu }+\delta_{10} \text { Mng } \exp +\omega_{i}
\end{aligned}
$$

where firmsize is a categorical variable for various firm sizes, age is the age of the firms, foreign is ownership of the firms (domestic and foreign), union is the existence of trade unions in the firms, reglabour is the labor regulations in the firms, corruption is the index of corruption, taxrates is the rate of taxes faced by the firm, accessfin is the access to finance by the firm, Mngedu is the manager's educational level (in continuous years) and Mngexp is the manager's experience. 


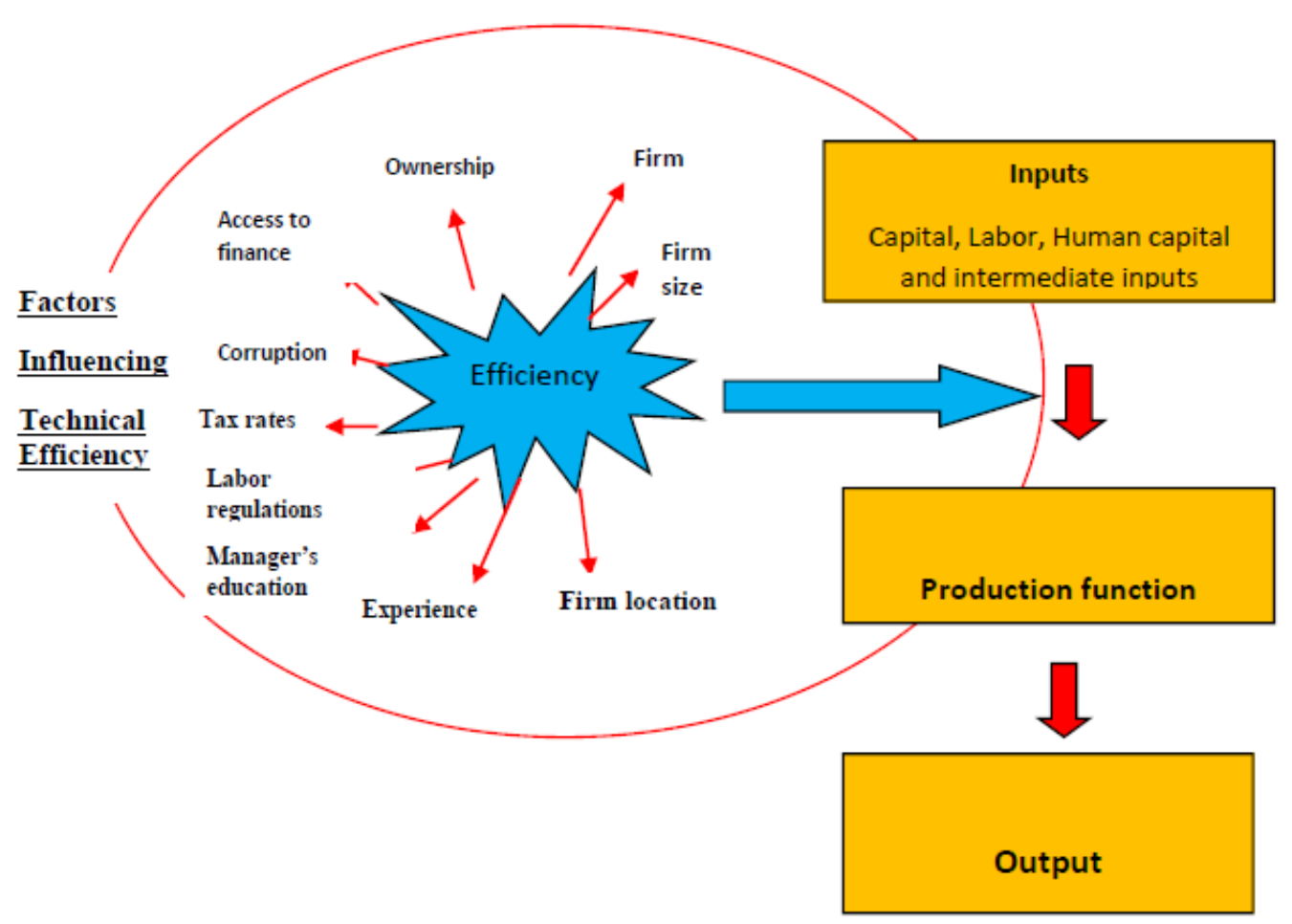

Figure 1. Conceptual model of manufacturing firms' technical efficiency

Source: Authors'

The production frontier specified in equation (3) and the inefficiency models defined by equation (4) above were jointly estimated by the maximum-likelihood (ML) method using FRONTIER 4.1 (Coelli, 1996). The FRONTIER software uses a three-step estimation method to obtain the final maximum likelihood estimates. First, estimates of the $\alpha$ - parameters are obtained by OLS. The two-phrase grid search for $\gamma$ is conducted in the second step with $\alpha$ - estimates set to the OLS values and other parameters set to zero. The third step involves an iterative procedure, using the Davidon-Fletcher-Powell Quasi-Newton method to obtain final maximum-likelihood estimates with the values selected in the grid search as starting values.

\section{Results and Discussion}

\subsection{Hypothesis Testing}

In estimating the production technology for the overall sample and five sectors of Cameroon's manufacturing firms, the Cobb-Douglas and trans-log production functions are specified for the empirical analysis. Based on Coelli and Battese (1996), various tests of hypotheses of the parameter in the frontier production function and the inefficiency models are performed using the generalized likelihood ratio test statistic, defined by the negative of twice the logarithm of the likelihood ratio as approximately the $\chi^{2}$ distribution with degree of freedom equal to the difference of the estimated parameters between the two nested hypotheses. Coelli and Battese (1996) defined the generalized likelihood ratio statistics as:

$$
\chi^{2}=-2\left[\log \left(L\left(H_{0}\right)\right)-\log \left(L\left(H_{1}\right)\right)\right]
$$

where $L\left(H_{0}\right)$ and $L\left(H_{1}\right)$ denote the values of the likelihood function under the null $\left(H_{0}\right)$ and the alternative $\left(H_{1}\right)$ hypotheses, respectively. If the null hypothesis is accepted, then the likelihood ratio test statistic has an approximately Chi-square or a mixed Chi-square distribution with degrees of freedom equal to the difference 
between the number of parameters in the unrestricted and restricted models. Two tests are performed;

Firstly on the functional form, the form of production function encompasses the Cobb-Douglas form (Cobb-Douglas is nested in the trans-log form). So the test of preference for one form over the other can be undertaken by analyzing the significance of the cross terms in the trans-log form.

Secondly, as concerns the inefficiency effects model, the null hypothesis is tested as: $H_{0}: \gamma=\delta_{0}=\delta_{1}=\ldots=\delta_{10}=0$, which specifies that the technical inefficiency effects are not present in the model, that is, manufacturing firms in Cameroon are efficient and have no room for efficiency growth.

Table 1. Test of hypothesis for technical efficiency

\begin{tabular}{|c|c|c|c|c|c|c|}
\hline $\begin{array}{c}\text { Food } \\
\text { Processing }\end{array}$ & Wood & $\begin{array}{c}\text { Textile and } \\
\text { Garments }\end{array}$ & $\begin{array}{l}\text { Metal and } \\
\text { Machinery }\end{array}$ & Electronics & $\begin{array}{l}\text { Overall } \\
\text { sample }\end{array}$ & $\begin{array}{l}\text { Critical } \\
\text { value }\end{array}$ \\
\hline \multicolumn{7}{|c|}{$H_{0}=\beta_{i}=0$ for all $i=1 \ldots 4($ Cobb - Douglas function $)$} \\
\hline $24.47 *$ & 17.58 & 17.02 & 16.79 & 16.54 & $36.32 *$ & 17.67 \\
\hline \multicolumn{7}{|c|}{$H_{0}: \gamma=\delta_{0}=\delta_{1}=\ldots=\delta_{10}=0($ No inefficiency effects $)$} \\
\hline $22.63 *$ & $19.65^{*}$ & $16.91 *$ & $15.57 *$ & $12.85^{*}$ & $32.9^{*}$ & 10.37 \\
\hline
\end{tabular}

Notes: * denotes cases where the null hypothesis is rejected. This happens when the calculated value exceeds the critical value. Critical values are obtained from Kodde and Palm (1982) and are at 5\% level of significance

The results from Table 1 show that the Cobb-Douglas production function is accepted for four sectors (Wood and furniture, Textile and Garments, Metals and Machinery, and Electronics), except for the food processing and the overall sample given the assumption of the trans-log production function. Therefore, the Cobb-Douglas function is specified for the four sectors whereas the trans-log specification is adopted for the food processing and the overall sample. The null hypothesis of no technical efficiency effects is rejected for all the sectors including the overall sample. Therefore, there are inefficiency effects in all the firms in the sample. This implies that, the traditional average (OLS) function is not suitable for estimating the results of the paper. Hence, the maximum likelihood estimation (MLE) method is applied.

\subsection{Technical Efficiency Analysis}

Table 2 reports the estimates of the Cobb-Douglas production functions for four sectors (Wood and furniture, Textile and Garments, Metals and Machinery, and Electronics) and the trans-log estimates for the food processing sector and the overall sample. The variables of the production function display the expected positive signs. The coefficients are generally significant at the conventional statistical level although the coefficient of expenditure on raw material is not significant for the two sectors. The results show that the elasticity of output with respect to labor dominates over capital. Similar results are obtained by Chapelle and Plane (2005) among Ivorian manufacturing sectors. This indicates that for specific policy formulation in addressing low productivity, there is a possibility of increasing the number of hours worked in the firms in Cameroon.

More so, an increase in total annual depreciation $(\mathrm{K})$ and average educational attainment $(\mathrm{H})$ will significantly and positively increase the firms' output. This shows that technical efficiency and output should increase with increase in the average educational attainment of the workers since education and capital replacement were expected to be positively correlated with technical efficiency. In Table 2, the negativity of the generalized log likelihood ratio shows the presence of the inefficiency term across all the sectors. 
Table 2. Cobb-Douglas and trans-log stochastic frontier estimation of technically efficiency

\begin{tabular}{|c|c|c|c|c|c|c|}
\hline Variable & $\begin{array}{l}\text { Food } \\
\text { Processing }\end{array}$ & $\begin{array}{l}\text { Wood \& } \\
\text { furniture }\end{array}$ & $\begin{array}{l}\text { Textile \& } \\
\text { Garments }\end{array}$ & $\begin{array}{l}\text { Metals and } \\
\text { Machinery }\end{array}$ & Electronics & $\begin{array}{l}\text { Overall } \\
\text { Sample }\end{array}$ \\
\hline \multirow[t]{2}{*}{ Constant } & 0.603 & "0.379 & 1.184 & $12.743 * * *$ & 0.046 & 1.431 \\
\hline & $(0.35)$ & $(0.17)$ & $(0.44)$ & $(4.26)$ & $(0.03)$ & $(1.38)$ \\
\hline \multirow[t]{2}{*}{ Loglabor $(L)$} & $0.748 * * *$ & $0.645^{* * *}$ & $0.660 * * *$ & 0.056 & $0.909 * * *$ & $0.651 * * *$ \\
\hline & $(7.16)$ & $(5.31)$ & $(4.31)$ & $(0.37)$ & $(10.11)$ & $(12.79)$ \\
\hline \multirow[t]{2}{*}{$\operatorname{Logcapital}(K)$} & 0.013 & 0.013 & $0.165^{*}$ & $-0.229 * *$ & $0.089 *$ & 0.03 \\
\hline & $(0.29)$ & $(0.19)$ & $(1.61)$ & $(-2.28)$ & $(1.54)$ & $(1.09)$ \\
\hline \multirow[t]{2}{*}{$\operatorname{Loghumcap}(\boldsymbol{H})$} & 0.323 & $0.249 *$ & -0.505 & 0.677 & $-0.871 * *$ & -0.056 \\
\hline & (1.13) & $(1.47)$ & $(-0.71)$ & $(1.14)$ & $(-2.12)$ & $(-0.34)$ \\
\hline \multirow[t]{2}{*}{ Logintermediate $(\boldsymbol{R})$} & $0.292 * * *$ & $0.405 * * *$ & $0.271 *$ & $0.49 * * *$ & $0.168 * *$ & $0.348 * * *$ \\
\hline & $(3.48)$ & $(3.91)$ & $(1.83)$ & $(3.69)$ & $(2.13)$ & $(8.42)$ \\
\hline \multirow[t]{2}{*}{$(1 / 2) \log (k * K)$} & 0.251 & & & & & 0.016 \\
\hline & $(0.39)$ & & & & & $(0.14)$ \\
\hline \multirow[t]{2}{*}{$(1 / 2) \log (L * L)$} & $0.115^{* * *}$ & & & & & $0.341 * * *$ \\
\hline & $(6.01)$ & & & & & $(8.32)$ \\
\hline \multirow[t]{2}{*}{$(1 / 2) \log (H * H)$} & 0.333 & & & & & $0.027 * *$ \\
\hline & $(0.13)$ & & & & & $(2.02)$ \\
\hline \multirow[t]{2}{*}{$(1 / 2) \log (R * R)$} & $0.219 * *$ & & & & & $0.115^{* *}$ \\
\hline & $(2.24)$ & & & & & $(2.35)$ \\
\hline \multirow[t]{2}{*}{$\log \left(K^{*} L\right)$} & $0.271 * * *$ & & & & & $0.239 * *$ \\
\hline & $(7.32)$ & & & & & $(1.98)$ \\
\hline \multirow[t]{2}{*}{$\log \left(K^{*} H\right)$} & -0.017 & & & & & -0.072 \\
\hline & $(-0.52)$ & & & & & $(-0.34)$ \\
\hline \multirow[t]{2}{*}{$\log \left(K^{*} R\right)$} & $-0.013 *$ & & & & & $0.299 * *$ \\
\hline & $(-1.40)$ & & & & & $(2.47)$ \\
\hline \multirow[t]{2}{*}{$\log \left(L^{*} H\right)$} & $0.422 * *$ & & & & & -0.362 \\
\hline & $(2.79)$ & & & & & $(-0.97)$ \\
\hline \multirow[t]{2}{*}{$\log (L * R)$} & $0.129 * *$ & & & & & $0.422 * *$ \\
\hline & $(2.33)$ & & & & & $(2.79)$ \\
\hline \multirow[t]{2}{*}{$\log \left(H^{*} L\right)$} & $0.196 *$ & & & & & -0.034 \\
\hline & $(1.92)$ & & & & & $(-0.39)$ \\
\hline Sigma-squared & 1.11 & 1.37 & 3.28 & 1.81 & 0.614 & 1.59 \\
\hline Lambda & 0.017 & 0.007 & 0.008 & 0.013 & 0.015 & 0.006 \\
\hline No. Obs. & 71 & 55 & 41 & 39 & 37 & 319 \\
\hline Wald Chi & 344.43 & 129.91 & 71.43 & 35.46 & 267.16 & 919.53 \\
\hline Prob $>$ Chi2 & $0.000 * * *$ & $0.000 * * *$ & $0.000 * * *$ & $0.000 * * *$ & $0.000 * * *$ & $0.000 * * *$ \\
\hline Mean TE & 0.724 & 0.653 & 0.555 & 0.498 & 0.631 & 0.619 \\
\hline Log-likelihood & -104.32 & -86.714 & -82.527 & -66.897 & -43.484 & -526.94 \\
\hline
\end{tabular}

Notes: $* * *, * * * *$ show significance level at $1 \%, 5 \%$ and $10 \%$ respectively. Values in parenthesis are the $\mathrm{z}$-values.

Sigma squared $\left(\sigma_{s}^{2}\right)=\sigma_{\varepsilon}^{2}+\sigma_{v}^{2}$.

Source: Authors 


\subsection{MLE of Stochastic Frontier Model Accounting for Heteroskedasticity}

Problems with efficiency estimation can arise when the variance of the dependent variable varies across the data, known as heteroscedasticity. Heteroscedasticity affects standard errors, and thus the determinations of significance of a given variable. Standard tests for heteroscedasticity following a linear regression are not available for frontier maximum likelihood estimation. However, the Cobb-Douglas function shows that the firms are using labor, capital, human capital and intermediate inputs in the production process with constant returns-to-scale technology, but the sizes of the firms differ. The size variation introduces heteroskedasticity into the idiosyncratic error term (Coelli, 1995). Stata allows for explicit modeling of variables thought to influence the variance of both $u_{i}$ and $v_{i}$, but an assumption of a half-normal inefficiency error term is required. Therefore, the parameters of the Cobb-Douglas are estimated taking into account the heteroskedastic effects. To do this, a conditional heteroskedastic half-normal model is used, with firm size as an explanatory variable in the variance function for the idiosyncratic error.

Table 3 indicates that the variance of the idiosyncratic error term $\left(\sigma_{v}^{2}\right)$ is not really a function of firm size in four of the five sectors considered. Heteroscedasticity only occurs in the wood and furniture industry. However, when the overall sample is considered, no strong pattern of heteroscedasticity is apparent. Therefore, the results suggest that heteroscedasticity is not a significant problem. The Wald chi tests and its corresponding probability for all the sectors indicate that the study fails to reject the hypothesis that the firms use constant returns to scale technology.

Table 3. Maximum Likelihood Estimation of Cobb-Douglas and Stochastic frontier models accounting for Heteroscedasticity (Half-normal Maximum Likelihood Estimation)

\begin{tabular}{|c|c|c|c|c|c|c|}
\hline Variable & $\begin{array}{l}\text { Food } \\
\text { Processing }\end{array}$ & $\begin{array}{l}\text { Wood \& } \\
\text { Furniture }\end{array}$ & $\begin{array}{l}\text { Textile \& } \\
\text { Garments }\end{array}$ & $\begin{array}{l}\text { Metals \& } \\
\text { Machinery }\end{array}$ & Electronics & $\begin{array}{l}\text { Overall } \\
\text { Sample }\end{array}$ \\
\hline \multirow[t]{2}{*}{ Constant } & 0.326 & -2.099 & -0.804 & $10.799 * * *$ & 0.097 & $1.459^{*}$ \\
\hline & $(0.25)$ & $(-1.27)$ & $(-0.39)$ & $(3.48)$ & $(0.06)$ & $(1.83)$ \\
\hline \multirow[t]{2}{*}{ Loglabor $(L)$} & $0.741 * * *$ & $0.846^{* * *}$ & $0.676^{* * *}$ & -0.041 & $0.902 * * *$ & $0.643^{* * *}$ \\
\hline & $(7.11)$ & $(9.16)$ & $(4.53)$ & $(-0.27)$ & $(9.73)$ & $(12.14)$ \\
\hline \multirow[t]{2}{*}{ Logcapital (K) } & 0.001 & 0.033 & $0.226^{* *}$ & -0.148 & $0.089^{*}$ & 0.031 \\
\hline & $(0.02)$ & $(0.54)$ & $(2.14)$ & $(-1.27)$ & $(1.55)$ & $(1.13)$ \\
\hline \multirow[t]{2}{*}{ Loghumcap $(H)$} & 0.321 & 0.623 & -0.289 & 0.212 & -0.847 & -0.071 \\
\hline & $(1.20)$ & $(1.28)$ & $(-0.47)$ & $(0.30)$ & $(-0.20)$ & $(-0.42)$ \\
\hline \multirow[t]{2}{*}{ Loginterinputs $(R)$} & $0.323 * * *$ & $0.306 * * *$ & $0.304 * *$ & $0.644 * * *$ & $0.171 * *$ & $0.354 * * *$ \\
\hline & $(3.78)$ & $(3.64)$ & $(2.48)$ & $(3.88)$ & $(2.18)$ & $(8.29)$ \\
\hline \multirow[t]{2}{*}{$(1 / 2) \log \left(k^{*} K\right)$} & 0.326 & & & & & 0.704 \\
\hline & $(0.41)$ & & & & & 0.32 \\
\hline \multirow[t]{2}{*}{$(1 / 2) \log \left(L^{*} L\right)$} & $0.02 * * *$ & & & & & $0.231 * * *$ \\
\hline & $(6.43)$ & & & & & 8.059 \\
\hline \multirow[t]{2}{*}{$(1 / 2) \log (H * H)$} & $0.085^{*}$ & & & & & 0.048 \\
\hline & $(1.55)$ & & & & & 0.88 \\
\hline \multirow[t]{2}{*}{$(1 / 2) \log (R * R)$} & $0.100^{*}$ & & & & & $0.059 *$ \\
\hline & $(1.68)$ & & & & & 1.76 \\
\hline \multirow[t]{2}{*}{$\log \left(K^{*} L\right)$} & $0.107 *$ & & & & & 0.081 \\
\hline & $(1.72)$ & & & & & 1.27 \\
\hline \multirow[t]{2}{*}{$\log \left(K^{*} H\right)$} & -0.558 & & & & & -0.564 \\
\hline & $(-0.29)$ & & & & & -0.23 \\
\hline \multirow[t]{2}{*}{$\log \left(K^{*} R\right)$} & $0.779 *$ & & & & & $0.600 *$ \\
\hline & $(1.45)$ & & & & & 1.69 \\
\hline \multirow[t]{2}{*}{$\log \left(L^{*} H\right)$} & -0.645 & & & & & $-0.052 *$ \\
\hline & $(-1.35)$ & & & & & -1.59 \\
\hline
\end{tabular}




\begin{tabular}{|c|c|c|c|c|c|c|}
\hline \multirow[t]{2}{*}{$\log \left(L^{*} R\right)$} & \multicolumn{5}{|l|}{$0.116^{* *}$} & $0.066^{*}$ \\
\hline & \multicolumn{5}{|l|}{ (1.96) } & 1.57 \\
\hline \multirow[t]{2}{*}{$\log \left(H^{*} L\right)$} & \multicolumn{5}{|l|}{-0.535} & -0.458 \\
\hline & \multicolumn{5}{|l|}{$(-0.41)$} & -1.06 \\
\hline \multirow{2}{*}{ Firmsize } & -0.463 & $1.037 * * *$ & -1.288 & -0.575 & 0.125 & -0.073 \\
\hline & $(-1.37)$ & $(3.90)$ & $(-1.35)$ & $(-1.26)$ & $(0.28)$ & $(-0.57)$ \\
\hline \multirow[t]{2}{*}{ Constant } & $1.072 *$ & $-2.009 * * *$ & $3.815 * * *$ & $1.617^{*}$ & -0.756 & $0.614 * *$ \\
\hline & $(1.79)$ & $(-3.45)$ & (2.73) & $(1.85)$ & $(-0.77)$ & $(2.25)$ \\
\hline No. Obs. & 71 & 55 & 41 & 39 & 37 & 319 \\
\hline Wald Chi & 363.54 & 311.29 & 103.24 & 42.17 & 243.71 & 923.86 \\
\hline Prob $>C h i$ & $0.000 * * *$ & $0.000 * * *$ & $0.000 * * *$ & $0.000 * * *$ & $0.000 * * *$ & $0.000 * * *$ \\
\hline Log-likelihood & -102.7 & -79.456 & -80.993 & -66.179 & -43.445 & -526.773 \\
\hline
\end{tabular}

Note: $(*),(* *)$, and $(* * *)$ show levels of significance at $10 \%, 5 \%$ and $1 \%$ respectively. The values in parenthesis are the z-values.

\subsection{Determinants of Inefficiency}

The focus of this section is to provide an empirical analysis of factors that contribute to technical inefficiency and productivity variability among manufacturing firms in Cameroon. Therefore, the estimated coefficients in the inefficiency model are presented in Table 4. The analysis of the inefficiency model shows that the signs of the estimated coefficients in the model have important implications on the technical efficiency of manufacturing firms. It should be noted that variables are included as inefficiency variables; thus a negative coefficient means an increase in efficiency and a positive effect on firms' output.

From Table 4, firm size is negatively correlated with firm technical inefficiency effects which imply a positive effect on productivity. The result conforms to a number of theoretical arguments. The literature of early development economics placed a strong emphasis on large firms, which were considered as the driving force of economic growth. Hence, small firms were being perceived as archaic modes of production. According to Chapelle and Plane (2005), large firms with their managerial know-how would offer a better organizational framework to reduce transaction cost. Hill and Kalirajan (1993) concluded with respect to Indonesian garment industry that large firms benefit from more efficient management. Thus the larger the size of a firm, the more labor is available for firms operations therefore increasing the efficiency of firms.

Firm age is also a major determinant of technical inefficiency of manufacturing firms in Cameroon as it reduces the efficiency of the firms. This is plausible given that majority of firms were established in the late 1970s (see appendix 1 for mean age of firms). The firms are old and may not be willing to try new innovation and technology due to financial constraints.

A significant relationship was found between the existence of trade union and the technical inefficiency levels of individual firms in the industries (except in the metal and machinery and electronics sub sectors). However, the variable has positive coefficients for the significant sub sectors. This shows that the variable explaining the existence of trade unions contributes significantly to technical inefficiency. 
Table 4. Inefficiency effect model

\begin{tabular}{|c|c|c|c|c|c|c|}
\hline Variable & $\begin{array}{l}\text { Food } \\
\text { Processing }\end{array}$ & $\begin{array}{l}\text { Wood \& } \\
\text { Furniture }\end{array}$ & $\begin{array}{l}\text { Textile \& } \\
\text { Garments }\end{array}$ & $\begin{array}{l}\text { Metals \& } \\
\text { Machinery }\end{array}$ & Electronics & $\begin{array}{l}\text { Overall } \\
\text { Sample }\end{array}$ \\
\hline \multirow[t]{2}{*}{ Firmsize } & $-0.454 * * *$ & $0.799 * * *$ & $-0.706^{*}$ & $0.280 *$ & $0.879 * *$ & $0.308 * *$ \\
\hline & $(-3.84)$ & $(2.75)$ & $(-1.66)$ & $(1.45)$ & $(2.23)$ & $(2.47)$ \\
\hline \multirow[t]{2}{*}{ Firmage } & $0.076^{* * *}$ & $0.023 *$ & 0.011 & $0.047 * * *$ & $0.059 * * *$ & $0.053 * * *$ \\
\hline & $(8.16)$ & $(1.43)$ & $(0.41)$ & $(3.29)$ & $(2.73)$ & $(6.76)$ \\
\hline \multirow[t]{2}{*}{ Foreign } & $-0.491 * * *$ & $-1.706^{* * *}$ & $-1.506^{*}$ & -0.455 & 0.751 & $-1.276^{* * *}$ \\
\hline & $(-8.76)$ & $(-3.31)$ & $(-1.68)$ & $(-0.99)$ & $(0.77)$ & $(-4.95)$ \\
\hline \multirow[t]{2}{*}{ Union } & $1.216^{*}$ & $0.487^{*}$ & $2.394 * * *$ & -0.166 & -0.391 & $1.068 * * *$ \\
\hline & $(1.75)$ & $(0.75)$ & $(2.95)$ & $(-0.46)$ & $(-0.51)$ & $(4.67)$ \\
\hline \multirow[t]{2}{*}{ Reglabor } & $0.442 * * *$ & 0.059 & $0.369 *$ & $0.387 * *$ & 0.202 & 0.028 \\
\hline & $(8.62)$ & $(0.38)$ & $(1.45)$ & $(2.18)$ & $(0.73)$ & $(0.34)$ \\
\hline \multirow[t]{2}{*}{ Corruption } & $0.245^{* * *}$ & $0.333 * *$ & 0.108 & 0.151 & $0.387 *$ & 0.007 \\
\hline & $(8.62)$ & $(2.16)$ & $(0.28)$ & $(1.26)$ & (1.69) & $(0.10)$ \\
\hline \multirow[t]{2}{*}{ Taxrates } & $-0.335^{* * *}$ & -0.007 & 0.007 & $-0.325^{* *}$ & 0.165 & 0.022 \\
\hline & $(-5.40)$ & $(-0.03)$ & $(0.03)$ & $(-2.61)$ & $(0.62)$ & $(0.26)$ \\
\hline \multirow[t]{2}{*}{ Acessfin } & $-0.428 * * *$ & -0.136 & -0.042 & -0.107 & $0.600 *$ & -0.016 \\
\hline & $(-8.83)$ & $(-0.75)$ & $(-0.11)$ & $(-0.63)$ & (1.59) & $(-0.15)$ \\
\hline \multirow[t]{2}{*}{ Mngedu } & $-0.235 * * *$ & 0.104 & $0.277^{*}$ & 0.167 & -0.094 & $0.156^{* * *}$ \\
\hline & $(-5.94)$ & (1.06) & $(1.78)$ & $(-1.22)$ & $(-0.62)$ & $(3.03)$ \\
\hline \multirow[t]{2}{*}{ Mngexp } & $0.028 * * *$ & -0.0003 & -0.003 & -0.019 & -0.020 & $-0.019 *$ \\
\hline & $(11.05)$ & $(-0.02)$ & $(-0.07)$ & $(-1.04)$ & $(-0.68)$ & $(-1.73)$ \\
\hline \multirow[t]{2}{*}{ Constant } & $22.061 * * *$ & $18.686^{* * * *}$ & $19.987 * * *$ & $17.642 * * *$ & $14.872 * * *$ & $17.745^{* * *}$ \\
\hline & $(3.25)$ & $(6.27)$ & $(9.62)$ & $(8.71)$ & $(4.20)$ & $(6.35)$ \\
\hline
\end{tabular}

Note: $* * *, * *, *$ shows levels of significance at $1 \%, 5 \%$ and $10 \%$ respectively. The values in parenthesis show the Z-statistics.

Another important variable which has an effect in determining technical efficiency level is the foreign ownership variable. It is significant in the food processing and beverages, wood processing, textile and garments as well as in the overall sample. Hence, it increases technical efficiency in the sub-sectors. Finally, the results also show that corruption plays a significant role in increasing technical inefficiency especially in all the subsectors as indicated by the positive coefficient of the variable.

\subsection{Mean Technical Efficiency and Inefficiency Scores}

Table 5 shows the mean technical inefficiency in all the sub sectors and for the overall sample. Technical efficiency is defined as: $T E_{i}=\frac{y_{i}}{y_{i}^{*}}=\exp \left(-u_{i}\right)$; where $y_{i}^{*}$ is the production frontier - maximum output given the inputs for 
each firm. Hence, $T E_{i}=\exp \left(-u_{i}\right)$. Therefore, in all specifications, total average technical efficiency would be: $\overline{T E}=\frac{1}{I} \sum_{i=1}^{I} T \hat{E}_{i}$, for each firm, $i=1,2 \ldots I$ (Coelli et al. 2005). From the technical efficiency equation, average inefficiency is calculated as; $1-\overline{T E}$.

Table 5. Mean technical inefficiency by size and sector

\begin{tabular}{lllllll}
\hline Size/Sector & $\begin{array}{l}\text { Food } \\
\text { Processing }\end{array}$ & $\begin{array}{l}\text { Wood \& } \\
\text { Furniture }\end{array}$ & $\begin{array}{l}\text { Textile \& } \\
\text { Garment }\end{array}$ & $\begin{array}{l}\text { Metals \& } \\
\text { Machinery }\end{array}$ & Electronics & $\begin{array}{l}\text { Overall } \\
\text { Sample }\end{array}$ \\
\hline Small & 0.187 & 0.210 & 0.204 & 0.206 & 0.194 & 0.184 \\
SD & $(0.142)$ & $(0.169)$ & $(0.155)$ & $(0.157)$ & $(0.136)$ & $(0.152)$ \\
Medium & 0.103 & 0.181 & 0.177 & 0.145 & 0.113 & 0.159 \\
SD & $(0.044)$ & $(0.132)$ & $(0.129)$ & $(0.080)$ & $(0.045)$ & $(0.157)$ \\
Large & 0.227 & 0.236 & 0.241 & 0.224 & 0.240 & 0.236 \\
SD & $(0.183)$ & $(0.188)$ & $(0.186)$ & $(0.185)$ & $(0.175)$ & $(0.183)$ \\
\hline
\end{tabular}

Notes: Values in parenthesis are the standard deviations for the mean technical efficiencies.

1) Small shows firms with less than 30 employees

2) Medium represent firms with 30 to 100 employees

3) Large represent firms with over 100 employees.

As shown in Table 5, total average technical inefficiency ranges from $10.3 \%$ to $24.1 \%$ across the five sectors. For the food processing sector, the average inefficiency varies widely, from $10.3 \%$ in medium sized firms to $22.7 \%$ in large firms. Inefficiency in the wood and furniture sector varies across firm sizes from $18.1 \%$ to $23.6 \%$. Taking the overall sample, inefficiency of for-profit varies in the firms across sizes from $15.9 \% \%$ to $23.6 \%$. Thus, the wood and furniture sector is the least efficient amongst the five sectors, followed by the textile and garments sector. The results also show that the food processing sector is the most efficient sector in the sample. Such a result could be due to the fact that the food processing sector has experienced higher technical change than the other sectors in the manufacturing sector, which could have pushed the production frontier further for some firms in the sector. It may also be as a result of economies of scale due to the high demand for food products.

As concerns firm size, the medium sized firms are found to be most efficient while large firms are found to be the most inefficient. Although some studies have found a positive relationship between technical efficiency and firm size (Lundvall and Battese, 2000; Niringiye et al., 2010), the findings in this present study are in conformity with Biggs et al. (1995) who found an inverted U-shaped relationship between firm size and efficiency. They found the size-efficiency relationship to be negative for large firms and positive for small firms, with the medium-sized firms being the most efficient. 
Table 6. Mean technical inefficiency by ownership and age for overall sample

\begin{tabular}{lcc}
\hline Variable & Inefficiency \\
\hline Ownership & & \\
& Domestic firms & $31.02 \%$ \\
& Foreign firms & $28.77 \%$
\end{tabular}

Firm Age
$0-5$ years
$30.15 \%$
$6-10$ years
$23.07 \%$
11 - 20 years
$27.32 \%$
20 and above
$35.97 \%$

Notes: 1) Ownership is measured by number of shares owned in the firm.

2) Firm age has been calculated as 2009 minus the year the firm started operations in Cameroon.

Table 6 above shows that foreign owned firms are more efficient than domestic owned firms. This might be explained by the issue of transfer technology especially as most of the foreign owned firms in Cameroon export to other countries. Learning by exporting, in which experience brings about improvements in performance, may be the explanation for the finding. Concerning firm age, firms between 6 to 10 years are the most efficient while the much older firms are the least efficient. This might be explained by the fact that at the start of the operations ( 0 to 5years), firms might still be adjusting to cover sunk cost and enter the market where (when) already established firms are operating. More so, in the context of Cameroon, the high inefficiency of the older firms might be explained by the type of technology used in the production process. Some of the technology is highly considered to by archaic and out dated. Therefore, older firms operate $35.97 \%$ below their potential frontier production level with the given inputs and production technology.

\section{Conclusion}

The primary objective of the study is to analyze the determinants of efficiency in manufacturing firms in Cameroon. The model used is that outlined by Battese and Coelli (1995) which determines the causes of inefficiency in the manufacturing sector in Cameroon. The estimates of the stochastic production frontier with inefficiency effects model indicate that firms in Cameroon exhibit various degrees of technical inefficiency for the sample of firms considered. The results show that firm size plays an important role in explaining technical efficiency in the sub-sector of food processing. However, large firms reduce technical inefficiency levels of firms in all the sub sectors. A significant relationship is found between trade unions existence and the technical inefficiency levels of individual firms in the industries (except in the wood and furniture and metal and furniture sub sectors). The age of firms also play an important role in determining inefficiency levels in the industry. This could be explained by the fact that most of the older firms were established in the post-colonial periods and still heavily rely on the outdated technology.

Another important variable which has an effect in determining technical efficiency level is the foreign variable. It is significant in food processing, wood processing, textile and garments as well as in the overall sample. Hence, it increases technical efficiency in all the sub-sectors. The results also show that corruption plays a significant role in increasing technical inefficiency especially in the food processing sector. Finally, since an increase in age of firms leads to a reduction in efficiency levels in manufacturing firms, policies should be adopted to replace the existing capital in the large firms.

\section{References}

Aigner, D., Lovell, K., \& P. Schmidt. (1977). Formulation and Estimation of Stochastic Frontier Production Function Models. Journal of Econometrics, 6, 21-37. https://doi.org/10.1016/0304-4076(77)90052-5

Aigner, D.J., \& Chu, S.F. (1968). On Estimating the Industry Production Function. American Economic Review, $58(4), 826-39$.

Battese G.E., \& T. J. Coelli. (1995). A model for technical inefficiency effects in a stochastic production function for panel data. Empirical Economics, 20, 325-332. https://doi.org/10.1007/BF01205442

Biggs, T., Shah, M., \& Srivastava, P. (1995). Technological capabilities and learning in African enterprises. World 
Bank Technical Paper number 288, Africa Technical Department Series, Washington, D.C.

Chapelle, K., \& P. Plane. (2005). Technical Efficiency measurement within the Manufacturing Sector in Cote d'Ivoire: A Stochastic Frontier Approach. The Journal of Development Studies, 41(7), 1303-1324. https://doi.org/10.1080/00220380500170964

Coelli, T., Prasada Rao, D. S., O'Donnell, C. J., \& Battese, G. E. (2005). An Introduction to Efficiency and Productivity Analysis (2nd ed.). New York: Springer.

Coelli, T.J. (1996). A guide to FRONTIER 4.1: A computer program for Frontier production function estimation. Centre for Efficiency and Productivity Analysis (CEPA), working paper 96/07, Department of Economics, University of New England, Australia.

Coelli, T.J., \& Battese, G. (1996). Identification of factors which influence the technical inefficiency of Indian farmers. American Journal of Agricultural Economics, 40(2), 103-128. https://doi.org/10.1111/j.1467-8489.1996.tb00558.x

Farrell, M.J. (1957). The measurement of productive efficiency. Journal of the Royal Statistical Society, Series A, 120(3), 253-290. https://doi.org/10.2307/2343100

Hill, H., \& K. Kalirajan. (1993). Small Enterprise and Firm-Level Technical Efficiency in Indonesian Garment Industries. Applied Economics, 25(9), 1137-44. https://doi.org/10.1080/00036849300000174

Kodde, D.A., \& F.C. Palm. (1986). Wald Criteria for Jointly Testing Equality and Inequality Restrictions. Econometrica, 54(5), 1243-48. https://doi.org/10.2307/1912331

Lundvall, K., \& E. Battese. (2000). Firm size, age and efficiency: Evidence from Kenyan Manufacturing firms. Journal of Development Studies, 36(3), 146-163. https://doi.org/10.1080/00220380008422632

Niringiye, A., \& E. Luvanda. (2010). Determinants of Export Participation in East African Manufacturing Firms. Current Research Journal of Economic Theory, 2(2), 55-61.

Niringiye, A., Luvanda, E., \& J. Shitundu. (2010). The relationship between Firm size and Technical Efficiency in East Africa Manufacturing Firms. Journal of Sustainable Development in Africa, 12(4), 226-236.

Njikam, O. (2003). Trade reforms and efficiency in Cameroon's Manufacturing Industries. AERC Research Paper 133 OECD, 2011, Cameroon. Tunis: AfDB/OECD.

Njikam, O., \& J. Cockburn. (2007). Trade liberalization and productivity growth: Firm-level evidence from Cameroon. PEP research paper, Canada.

Njikam, O., Bamou, E., \& C. N'donga. (2008). The case of the Manufacturing Sector in Cameroon. An AERC Publication on African imperatives in the New World Trade order, Vol. 2, Case studies of Manufacturing and Services.

Oczkowski, E., \& K. Sharma. (2005). Determinants of efficiency in Least Developed Countries: Further evidence from Napelese manufacturing firms. Journal of Development Studies, 41(4), 617-630. https://doi.org/10.1080/00220380500092721

RPED. (2010). Regional Program for Enterprise Development (RPED) report, Cameroon, 2010.

Schmidt, P., \& C. Sickles C. (1984). Production frontiers and panel data. Journal of Business and Economic Statistics, 2, 367-374. https://doi.org/10.1080/07350015.1984.10509410

Schmidt, P., \& C.A.K. Lovell. (1979). Estimating technical and allocative ineficiency relative to stochastic production and cost frontiers. Journal of Econometrics, 9, 343-366. https://doi.org/10.1016/0304-4076(79)90078-2

Soderling, L. (1999). Structural policies for international competiveness in manufacturing: the case of Cameroon. Working paper No. 146, OECD Development Centre.

Tambi, E.N. (1984). Agricultural development policy and performance in Cameroon, 1960-1980', PhD thesis, University of Pittsburgh, USA.

Taymaz, E., \& G. Saatci, (1997). Technical change and efficiency in Turkish manufacturing Industries. Journal of Productivity Analysis, 8, 461-475. https://doi.org/10.1023/A:1007796311574 


\section{Appendices}

Appendix 1. Distribution of firms according to size, age, sector of activity and by regions in Cameroon

Table 7. Distribution of firms according to size, age and sector of activity

\begin{tabular}{|c|c|c|c|c|c|c|c|c|c|c|c|c|c|}
\hline & \multicolumn{8}{|c|}{ Sector of Activity and sizes of firm } & \multicolumn{5}{|c|}{ Age of firm } \\
\hline & Food & Wood & Textile & Metal & Electronics & Non metal & others & Total & {$[0,5]$} & $(5,10]$ & $(10,20]$ & $(20,+)$ & Total \\
\hline Small $(<20)$ & 15 & 15 & 11 & 16 & 8 & 14 & 19 & 86 & 4 & 21 & 23 & 38 & 86 \\
\hline Medium (20-99) & 27 & 26 & 20 & 13 & 16 & 11 & 29 & 129 & 7 & 15 & 38 & 69 & 129 \\
\hline Large (100 and above) & 29 & 14 & 10 & 10 & 13 & 11 & 20 & 104 & 6 & 13 & 30 & 55 & 104 \\
\hline Total & 71 & 55 & 41 & 39 & 37 & 26 & 68 & 319 & 17 & 49 & 91 & 162 & 319 \\
\hline
\end{tabular}

Source: Cameroonian firm level data base, RPED, World Bank.

Table 8. Distribution of firms by size and region in Cameroon

\begin{tabular}{lcccc}
\hline & Littoral (Douala) & Centre (Yaounde) & West (Bafoussam) & Total \\
\hline Small $(<20)$ & $38(31)$ & $6(9)$ & $2(0)$ & $46(40)$ \\
$\begin{array}{l}\text { Medium }(20-99) \\
\begin{array}{l}\text { Large }(100 \text { and } \\
\text { above) }\end{array}\end{array}$ & $58(41)$ & $5(15)$ & $4(6)$ & $67(62)$ \\
Total & $47(29)$ & $7(11)$ & $3(7)$ & $57(47)$ \\
\hline
\end{tabular}

Source: Cameroonian firm level database, RPED, World Bank.

Appendix 2. Summary statistics of variables in different sectors

\begin{tabular}{llllll}
\hline & Obs. & Mean & Std. Dev & Min. & Max. \\
\hline \multicolumn{1}{c}{ Food Processing } & & & & & \\
Log of Output & 71 & 20.8808 & 2.5621 & 15.4949 & 26.0846 \\
Log of labor & 71 & 18.8404 & 2.1716 & 14.5856 & 24.5945 \\
Log of capital & 71 & 17.8965 & 2.9496 & 10.8198 & 24.5945 \\
Log of human Capital & 71 & 1.14130 & 0.4482 & 0 & 1.6094 \\
Log of Intermediate Inputs & 71 & 19.1531 & 2.7453 & 12.4292 & 24.9159 \\
Firm age & 71 & 26.9437 & 26.944 & 1 & 61 \\
Mng exp.(Manager experience) & 71 & 16.3944 & 8.5815 & 2 & 40 \\
$\quad$ Wood and Furniture & & & & & \\
Log of Output & 55 & 19.566 & 2.1665 & 13.6412 & 25.1053 \\
Log of labor & 55 & 17.6469 & 1.7725 & 13.0815 & 23.0259 \\
Log of capital & 55 & 17.4585 & 2.4471 & 11.9087 & 23.3623 \\
Log of human Capital & 55 & 1.1955 & 0.3168 & 0 & 1.6094 \\
Log of Intermediate Inputs & 55 & 17.9509 & 1.1377 & 11.9184 & 22.1096 \\
Firm age & 55 & 22.8545 & 14.7226 & 4 & 61 \\
Mng exp. (Manager experience) & 55 & 18.4546 & 11.1186 & 3 & 50 \\
Tog of Output & & & & & \\
& 41 & 19.5606 & 2.9291 & 14.5087 & 25.3284
\end{tabular}




\begin{tabular}{|c|c|c|c|c|c|}
\hline Log of labor & 41 & 17.2192 & 2.3456 & 13.017 & 23.0259 \\
\hline Log of capital & 41 & 16.3661 & 3.2082 & 9.9688 & 23.3623 \\
\hline Log of human Capital & 41 & 1.1066 & 0.4037 & 0 & 1.6094 \\
\hline Log of Intermediate Inputs & 41 & 17.5829 & 2.6484 & 11.7906 & 22.7671 \\
\hline Firm age & 41 & 23.4878 & 11.485 & 4 & 47 \\
\hline Mng exp. (Manager experience) & 41 & 19.3659 & 8.8396 & 6 & 40 \\
\hline \multicolumn{6}{|c|}{ Metal and Machinery } \\
\hline Log of Output & 39 & 192733 & 1.8827 & 16.1181 & 24.2599 \\
\hline Log of labor & 39 & 17.3604 & 1.8581 & 13.5924 & 21.3609 \\
\hline Log of capital & 39 & 16.7419 & 2.2385 & 13.3047 & 23.1212 \\
\hline Log of human Capital & 39 & 1.1470 & 0.3929 & 0 & 1.6094 \\
\hline Log of Intermediate Inputs & 39 & 17.6146 & 2.1945 & 14.2209 & 22.9954 \\
\hline Firm age & 39 & 20.3333 & 16.1772 & 2 & 63 \\
\hline Mng exp. (Manager experience) & 39 & 19.8718 & 8.7934 & 3 & 45 \\
\hline \multicolumn{6}{|l|}{ Electronics } \\
\hline Log of Output & 37 & 19.1649 & 2.278 & 14.7318 & 14.6353 \\
\hline Log of labor & 37 & 17.2202 & 1.9963 & 13.6171 & 21.8219 \\
\hline Log of capital & 37 & 16.7325 & 2.3859 & 10.8198 & 23.1211 \\
\hline Log of human Capital & 37 & 1.2225 & 0.3296 & 0.6931 & 1.6094 \\
\hline Log of Intermediate Inputs & 37 & 17.9704 & 2.2241 & 12.5818 & 23.719 \\
\hline Firm age & 37 & 23.7027 & 13.824 & 5 & 76 \\
\hline Mng exp. (Manager experience) & 37 & 20.6487 & 8.1454 & 9 & 45 \\
\hline \multicolumn{6}{|c|}{ Overall Sample } \\
\hline Log of Output & 319 & 19.8927 & 2.4911 & 13.6412 & 26.0845 \\
\hline Log of labor & 319 & 17.839 & 2.0989 & 13.017 & 24.5945 \\
\hline Log of capital & 319 & 17.1322 & 2.6716 & 9.9688 & 24.5945 \\
\hline Log of human Capital & 319 & 1.1476 & 0.4242 & 0 & 1.6094 \\
\hline Log of Intermediate Inputs & 319 & 18.3764 & 2.5805 & 11.7906 & 24.9159 \\
\hline Firm age & 319 & 23.5047 & 15.0264 & 1 & 76 \\
\hline Mng exp. (Manager experience) & 319 & 18.4075 & 9.2684 & 2 & 50 \\
\hline
\end{tabular}

Source: Author's calculation using RPED dataset, World Bank 